\title{
Forty-YEAR Changes IN THE AVIFAUNA OF Grand Teton National Park, Wyoming, WITH EMPHASIS ON NEOTROPICAL MIGRANTS
}

\author{
STEPHANIE JONES $\downarrow$ USFWS $\bullet$ DENVER \\ FRITZ KNOPF $\bullet$ NBS, NERC $\bullet$ FORT COLLINS
}

\section{$-\quad$ INTRODUCTION}

Ornithologists and wildlife biologists have always been interested in documenting long-term changes in bird populations (e.g., Temple and Temple 1976, Kendeigh 1982). Long-term comparisons can assist in identifying patterns of change. These patterns, in turn, provide assistance in defining human impacts that may lead to some species or groups declining towards extirpation.

One study specifically (Wilcove 1988) has had a major impact upon current resource issues within the Fish and Wildlife Service. That study used 40-year comparisons to confirm that fragmentation of the eastern deciduous forest had led to declines of neotropical migrants. The Wilcove (1988) study along with an essay (Hutto 1988) and an ecological study in New Hampshire (Holmes and Sherry 1988) were fundamental in identifying that declines in this group of birds cannot be blamed solely upon changes on Latin American wintering grounds.

Missing from the neotropical migrant story, however, is an image of how neotropical migrants from western North America have changed in recent decades. An historical data set for comparison is available for seven vegetative associations in the vicinity of Jackson, Wyoming (Salt 1957).

This project was begun in 1993 to replicate
Salt's 1957 study in Grand Teton National Park. The work in 1993 was a pre-study to evaluate the potential for replicating Salt's study in the mid 1990 's, 40 years after the original work.

\section{$\checkmark \quad$ OBJECTIVES}

The specific objectives for the 1993 prestudy were to:

1. Relocate the 1952-1954 transects in Grand Teton NP (Jackson Hole, WY) in June of 1993.

2. Determine if a representative replicate of the earlier study is feasible in 1994-5.

\section{$\checkmark \quad$ METHODS}

This 1993 pre-study evaluation included relocating the 1950's transects and study areas and obtaining basic information on vegetation condition (relative to succession). The original study (Salt 1957) used line transects through seven vegetative communities: willow-sedge swamp, willow-scrub meadow, flatland aspen, hillside aspen, lodgepole pine, spruce-fir, and lodgepole pine-spruce-fir; however, only six communities were included in the discussion in the original paper. Hillside aspen was not analyzed separate from flatland aspen. 
In 1993, Dr. Salt was contacted and his field notes, maps, and photographs from the study and study areas were obtained. All of his original transects were relocated, and it was determined that only the hillside aspen and the willow-sedge swamp were no longer the same vegetative community. Line transects in the lodgepole pine, spruce-fir, lodgepole pine-spruce-fir, flatland aspen, and willow scrub meadow communities in the same stands used in the 1950's were identified.

Transects and point counts (Reynolds et. al. 1980) were combined in the flatland and hillside aspen communities that were not the same stands that Dr. Salt used. Transects were combined with area search techniques (Ralph et al. 1993) in the willowsedge swamp, near the area of the original transect.

\section{$\checkmark \quad$ STUdY AREAS (LOCATION)}

Grand Teton National Park: Paintbrush Canyon, aspen and willow stands near Jackson Lake and Moran, WY.

\section{$\checkmark \quad$ RESULTS}

The 1993 field season resulted in the location of all the original transects and study areas, including relocations for the two vegetation communities that had changed. The field notes and maps of Dr. Salt were so precise that locating the transects and evaluating the vegetation was completed in the first week. This resulted in a complete first year replicate of Dr. Salt's 1957 study.

In the 1994 field season, the 1954 field work in the three conifer habitats in Paintbrush Canyon will be replicated. Also, transects and point counts in the other vegetation communities will be completed for a more accurate estimate of bird use and populations in the these areas. After the 1994 field season, we will determine if another year is required. The final results of this study will be published in a peer reviewed journal.

\section{$\checkmark \quad$ LITERATURE CITED}

Holmes, R. T. and T. W. Sherry. 1988. Assessing population trends of New Hampshire forest birds: local vs. regional patterns. Auk 105:756-768.

Hutto, R. L. 1988. Is tropical deforestation responsible for the reported declines in neotropical migrant populations? Amer. Birds 42:375-379.

Kendeigh, S. C. 1982. Bird populations in east central Illinois: fluctuations, variations, and development over a half-century. Illinois Biol. Monog. 52:1-136.

Ralph, C.J., G.R. Geupel, P. Pyle, T.E. Martin, and D.F. DeSante. 1993. Handbook of field methods for monitoring landbirds. USDA, Forest Service, General Technical Publication PSW-GTR-144. Albany, California.

Reynolds, R.T., J. M. Scott, and R.A. Nussbaum. 1980. A variable circular-plot method for estimating bird numbers. Condor 82:309313.

Salt, G. W. 1957. An analysis of avifaunas in the Teton Mountains and Jackson Hole, Wyoming. Condor 59:373-392.

Temple, S. A. and B. L. Temple. 1976. Avian population trends in central New York state, 1935-1972. Bird-Banding 47:238257.

Wilcove, D.S. 1988. Changes in the avifauna of Great Smoky Mountains, 1947-1983. Wilson Bull. 100:256-271. 